\title{
Caring for the critically ill patients over 80: a narrative review
}

\author{
Bertrand Guidet ${ }^{1,2,3^{*}}$, Helene Vallet ${ }^{3,4}$, Jacques Boddaert ${ }^{2,4}$, Dylan W. de Lange ${ }^{5}$, Alessandro Morandi ${ }^{6,7}$, \\ Guillaume Leblanc ${ }^{8,9}$, Antonio Artigas ${ }^{10}$ and Hans Flaatten ${ }^{11,12}$
}

\begin{abstract}
Background: There is currently no international recommendation for the admission or treatment of the critically ill older patients over 80 years of age in the intensive care unit (ICU), and there is no valid prognostic severity score that includes specific geriatric assessments.

Main body: In this review, we report recent literature focusing on older critically ill patients in order to help physicians in the multiple-step decision-making process. It is unclear under what conditions older patients may benefit from ICU admission. Consequently, there is a wide variation in triage practices, treatment intensity levels, end-of-life practices, discharge practices and frequency of geriatrician's involvement among institutions and clinicians. In this review, we discuss important steps in caring for critically ill older patients, from the triage to long-term outcome, with a focus on specific conditions in the very old patients.
\end{abstract}

Conclusion: According to previous considerations, we provide an algorithm presented as a guide to aid in the decision-making process for the caring of the critically ill older patients.

\section{Introduction}

In the past 20 years, there has been an increase in the elderly population admitted to the intensive care unit (ICU) $[1,2]$. Currently, the median age of critically ill patients approaches 65 years in many countries, and the proportion of the very old ( 80 years or over) critically ill patients will increase faster than any other cohort in the ICUs [3]. Intensive care unit resources use in the very old patients carries a high burden on healthcare costs $[4,5]$. In a Canadian study, the average cost of an ICU admission of patients 80 years or over was $\$ 31,679$ [4]. Undeniably, caring for older patients frequently poses ethical and practical challenges both prior to and during ICU admission [6]. Such decision making requires an in-depth understanding of aging and its consequences on normal organ function, together with close communication with family and other caregivers [7].

\section{*Correspondence: bertrand.guidet@aphp.fr}

${ }^{1}$ Assistance Publique - Hôpitaux de Paris (AP-HP), Service de Réanimation

Médicale, Hôpital Saint-Antoine, 184 rue du Faubourg Saint-Antoine,

75012 Paris, France

Full list of author information is available at the end of the article
In this review, we will discuss important steps in caring for the critically ill patients 80 years or over, from the triage to discharge, long-term rehabilitation or palliative care. We will highlight recent researches and advances in this field and propose an algorithm that can be used as a guide in the decision-making process for the caring of the critically ill older patients (Fig. 1).

\section{Characterization of an old patient: lessons to be learnt from geriatricians \\ Aging}

There is no consensual definition of aging [8]. The World Health Organization considers anyone over 65 years old as "elderly." However, in the ICU, we commonly characterize patients 80 years or over as "very old." Aging is a complex transition that includes a physiological and cognitive vulnerability, making the individual more prone to diseases and acute medical events, leading to further decrease in reserve capacities, loss of functional independency and ultimately to death (Fig. 2). 


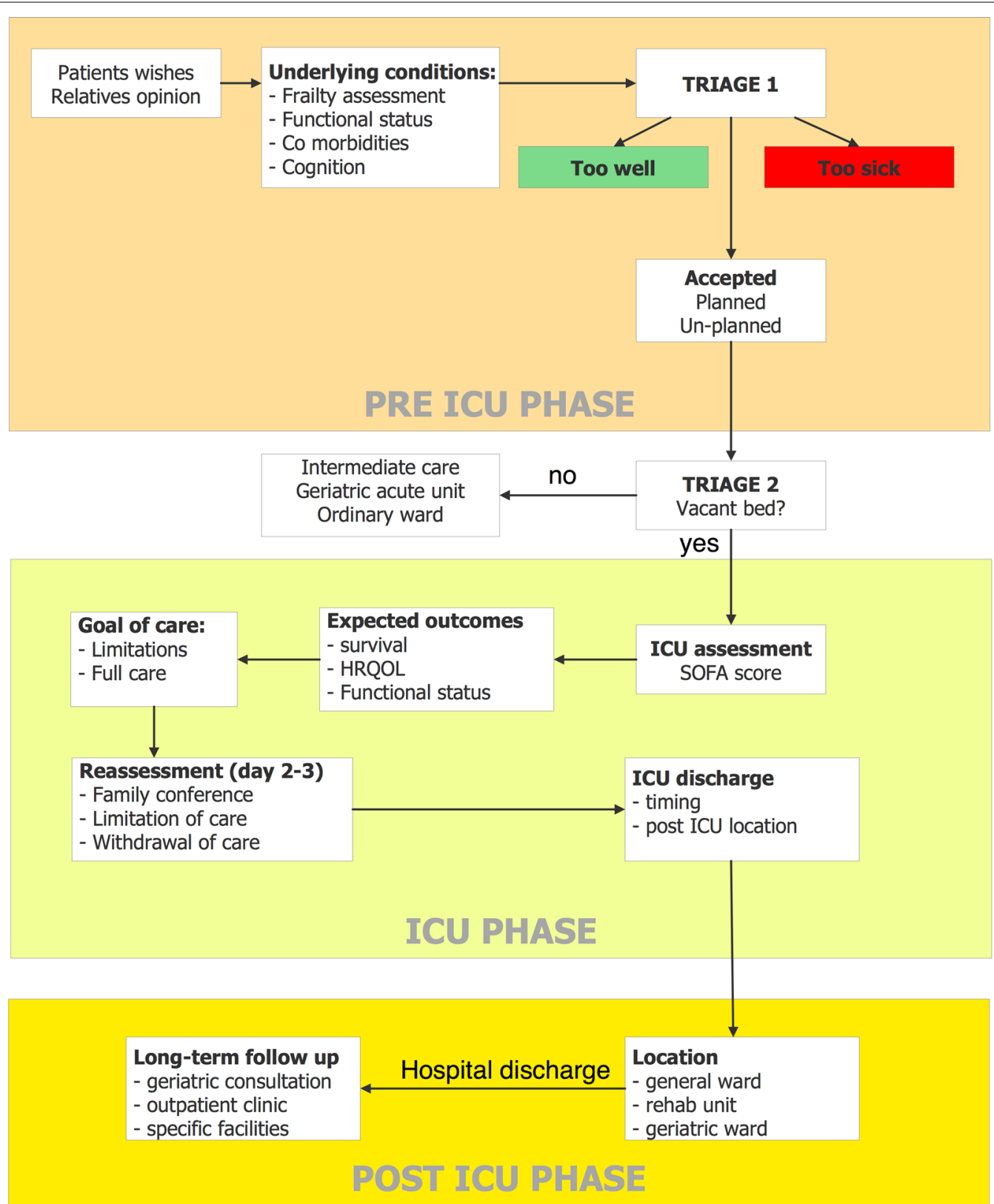

Fig. 1 Algorithm for critically ill patients over 80y

\section{Comorbidities}

The proportion of patients with comorbidities and the number of comorbidities per patients increase with age. The mean number of comorbidities per patients is $2.6 \pm 2.2$ in patients $65-84$ years old and $3.6 \pm 2.3$ in patients 85 years or over [9]. The most common comorbidities are hypertension, diabetes, chronic obstructive pulmonary disease, cardiac failure, cancer and cognitive impairment $[9,10]$. Comorbidities are associated with an increased mortality [11], loss in physical independency and an increase in hospitalization rates [12]. In ICUs, comorbidities are associated with higher in-hospital [13, 14] and long-term mortality rates [15]. The Charlson comorbidity index (Table 1) has been validated in critically ill patients and is predictive of mortality $[15,16]$.

Physiological changes leading to the decrease in reserve capacities have been extensively described [17-20]. Advanced age leads to an alteration in respiratory physiology (loss of elastic lung tissue, increased anteroposterior diameter of the chest, decreased muscle 


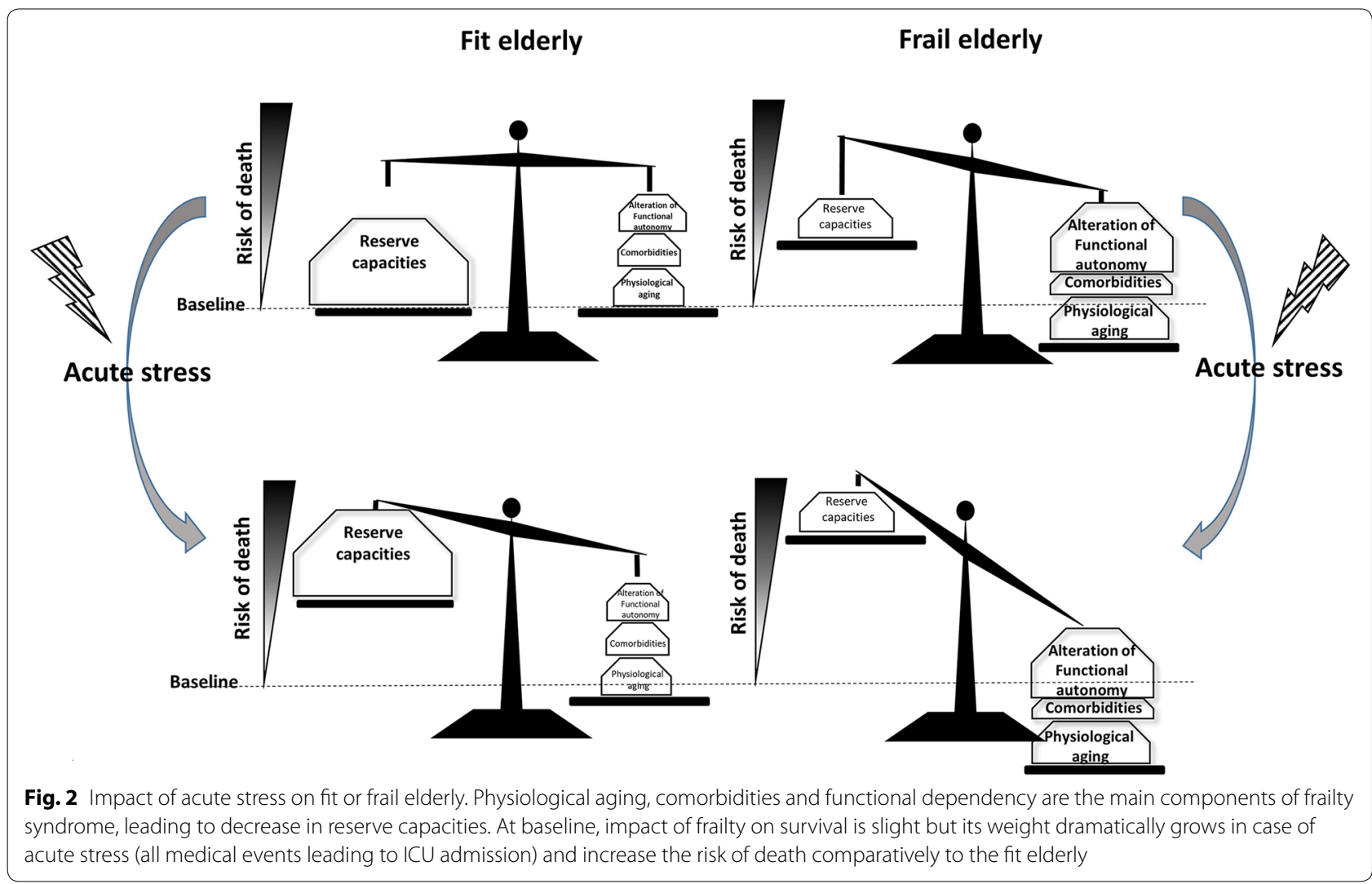

strength and sensitivity of respiratory centers to hypoxemia and hypercapnia) leading to increased risk of acute respiratory failure and mortality. The combination of immunosuppression and "inflamm-aging," called "immunosenescence," results in higher rates of viral reactivation and infection susceptibility and severity.

\section{Malnutrition}

Malnutrition affects $12-45 \%$ of hospitalized older patients and is associated with longer hospital length of stay, poor physical independency, poor quality of life and higher mortality $[21,22]$. Furthermore, malnutrition importantly contributes to "frailty" [23]. In critically ill patients, malnutrition and negative protein-energy balance are associated with higher ICU length of stay, mortality, rate of acquired infection and length of mechanical ventilation [24].

\section{Cognitive impairment}

Prevalence of preexisting cognitive impairment at ICU admission ranges from 6 to $43 \%[25,26]$. In the ICU, cognitive impairment is a strong risk factor for delirium $[27,28]$, which is associated with increased mortality and with subsequent further cognitive and executive function decline $[25,29]$.

\section{Functional decline and frailty}

General assessment of baseline functional status is crucial. Several scales estimate physical dependency, like the Activities of Daily Living scale and Instrumental Activities of Daily Living scale (Table 1) [30, 31]. In clinical practice, a simplified version of Instrumental Activities of Daily Living scale is used [32].

The "frailty syndrome" is defined as an individual's inherent vulnerability leading to difficulties to overcome acute stress [33, 34]. The frailty model includes areas such as physiological functioning, comorbidities, functional impairment and social difficulties [34, 35]. An easy-to-use Clinical Frailty Scale (CFS) was proposed in 2008, ranking patients in nine group from "very fit" to "terminally ill" (Table 1) (Additional file 1) [36, 37]. An increased CFS is associated with a higher risk of mortality [36]. Furthermore, frailty is associated with a higher risk of falls, worsening mobility and institutional care [38]. A recent meta-analysis concludes that there is a higher risk of not returning to home and a higher risk of in-hospital and long-term mortality in frail patients admitted to the ICU [33]. In the VIP1 study, which included 5132 critically ill patients $\geq 80$ years from 311 European ICUs, frailty (CFS > 4) was present in $43.1 \%$ and was independently related to ICU (22.2\%) and 30-day mortality (35.8\%) [39]. 
Table 1 Summary of main scales used in geriatric evaluation

Comorbidities

Charlson comorbidity index [16]

Functional autonomy

ADL scale [30]

Age (years old)

$$
\begin{aligned}
& \text { 50-59 (1 point) } \\
& \text { 60-69 ( } 2 \text { points) } \\
& \text { 70-79 (3 points) } \\
& \geq 80 \text { (4 points) } \\
& \text { Diabetes }
\end{aligned}
$$

Uncomplicated (1 point)

End-organ damage (2 points)

Liver disease

Mild (1 point)

Moderate to severe (3 points)

Malignancy

Any leukemia, lymphoma or localized solid tumor (2 points)

Metastatic solid tumor (6 points)

AIDS (6 points)

Moderate-to-severe renal disease (2 points)

Congestive heart failure (1 point)

Myocardial infarction (1 point)

Chronic pulmonary disease (1 point)

Peripheral vascular disease (1 point)

Cerebrovascular disease (1 point)

Dementia (1 point)

Hemiplegia (2 points)

Connective tissue disease (1 point)

Peptic ulcer disease (1 point)

Bathing (independent: 1 point; partially dependent: 0,5 point; totally dependent: 0 point)

Dressing (independent: 1 point; partially dependent: 0,5 point; totally dependent: 0 point)

Toileting (independent: 1 point; partially dependent: 0,5 point; totally dependent: 0 point)

Transfer (independent: 1 point; partially dependent: 0,5 point; totally dependent: 0 point)

Continence (independent: 1 point; partially dependent: 0,5 point; totally dependent: 0 point)

Feeding (independent: 1 point; partially dependent: 0,5 point; totally dependent: 0 point)

Scale from 0 (totally dependent) to 6 (independent)

IADL scale [31]
Ability to use telephone

Operates telephone on own initiative; looks up and dials numbers (1 point)

Dials a few well-known numbers (1 point)

Answers telephone, but does not dial (1 point)
Table 1 (continued)

Shopping

Takes care of all shopping needs independently (1 point)

Shops independently for small purchases (0 point)

Needs to be accompanied on any shopping trip (0 point)

Completely unable to shop (0 point)

Food preparation

Plans, prepares and serves adequate meals independently (1 point)

Prepares adequate meals if supplied with ingredients ( 0 point)

Heats and serves prepared meals or prepares meals but does not maintain adequate diet (0 point)

Needs to have meals prepared and served (0 point)

Housekeeping

Maintains house alone with occasion assistance (heavy work) (1 point)

Performs light daily tasks such as dishwashing, bed making (1 point)

Performs light daily tasks, but cannot maintain acceptable level of cleanliness (1 point)

Needs help with all home maintenance tasks (1 point)

Does not participate in any housekeeping tasks (0 point)

Laundry

Does personal laundry completely (1 point)

Launders small items, rinses socks, stockings, etc. (1 point)

All laundry must be done by others ( 0 point)

Mode of transportation

Travels independently on public transportation or drives own car (1 point)

Arranges own travel via taxi, but does not otherwise use public transportation (1 point)

Travels on public transportation when assisted or accompanied by another (1 point)

Travel limited to taxi or automobile with assistance of another ( 0 point)

Does not travel at all (0 point)

Responsibility for own medications Is responsible for taking medication in correct dosages at correct time (1 point)

Takes responsibility if medication is prepared in advance in separate dosages (0 point)

Is not capable of dispensing own medication (0 point) 
Table 1 (continued)

\begin{tabular}{|c|c|}
\hline & Ability to handle finances \\
\hline & $\begin{array}{l}\text { Manages financial matters independently } \\
\text { (budgets, writes checks, pays rent and } \\
\text { bills, goes to bank); collects and keeps } \\
\text { track of income (1 point) }\end{array}$ \\
\hline & $\begin{array}{l}\text { Manages day-to-day purchases, but needs } \\
\text { help with banking, major purchases, etc. } \\
\text { (1 point) }\end{array}$ \\
\hline & Incapable of handling money (0 point) \\
\hline $\begin{array}{l}\text { Scale from } 0 \text { (low functior } \\
\text { ent) }\end{array}$ & lependent) to 8 (high function/independ- \\
\hline Frailty & \\
\hline $\begin{array}{l}\text { Rockwood Clinical Frailty } \\
\text { Scale [36] }\end{array}$ & $\begin{array}{l}\text { 1. Very fit-People who are robust, active, } \\
\text { energetic and motivated. These people } \\
\text { commonly exercise regularly. They are } \\
\text { among the fittest for their age }\end{array}$ \\
\hline & $\begin{array}{l}\text { 2. Well_People who have no active disease } \\
\text { symptoms but are less fit than category } \\
\text { 1. Often, they exercise or are very active } \\
\text { occasionally, e.g., seasonally }\end{array}$ \\
\hline & $\begin{array}{l}\text { 3. Managing well_-People whose medical } \\
\text { problems are well controlled, but are not } \\
\text { regularly active beyond routine walking }\end{array}$ \\
\hline & $\begin{array}{l}\text { 4. Vulnerable-While not dependent on } \\
\text { others for daily help, often symptoms } \\
\text { limit activities. A common complaint is } \\
\text { being "slowed up," and/or being tired } \\
\text { during the day }\end{array}$ \\
\hline & $\begin{array}{l}\text { 5. Mildly frail-These people often have } \\
\text { more evident slowing and need help in } \\
\text { high-order IADLs (finances, transporta- } \\
\text { tion, heavy housework, medications). } \\
\text { Typically, mild frailty progressively impairs } \\
\text { shopping and walking outside alone, } \\
\text { meal preparation and housework }\end{array}$ \\
\hline & $\begin{array}{l}\text { 6. Moderately frail_-People need help with } \\
\text { all outside activities and with keeping } \\
\text { house. Inside, they often have problems } \\
\text { with stairs and need help with bath- } \\
\text { ing and might need minimal assistance } \\
\text { (cuing, standby) with dressing }\end{array}$ \\
\hline & $\begin{array}{l}\text { 7. Severely frail_CCompletely dependent } \\
\text { for personal care, from whatever cause } \\
\text { (physical or cognitive). Even so, they } \\
\text { seem stable and not at high risk of dying } \\
\text { (within } \sim 6 \text { months) }\end{array}$ \\
\hline & $\begin{array}{l}\text { 8. Very severely frail—Completely depend- } \\
\text { ent, approaching the end of life. Typically, } \\
\text { they could not recover even from a minor } \\
\text { illness }\end{array}$ \\
\hline & $\begin{array}{l}\text { 9. Terminally ill_Approaching the end of } \\
\text { life. This category applies to people with a } \\
\text { life expectancy }\end{array}$ \\
\hline
\end{tabular}

AIDS Acquired Immunodeficiency Syndrome, $A D L$ activity of daily living, IADL Instrumental Activities of Daily Living

\section{Medications: a special concern in old patients}

The problem of medication and its biodisponibility in old patients have been well described since 1980 [40, 41]. Polypharmacy and inappropriate medications prescription among older patients are receiving increasing attention [42, 43] as it frequently leads to adverse outcomes $[44,45]$. In particular, acute hospitalizations pose an increased risk of inappropriate prescription because of newly prescribed medications, the presence of multiple prescribers, inadequate medication reconciliation and a lack of care coordination [46].

Medications typically intended for short-term use during acute illness are sometimes continued after discharge without a documented indication [47]. While it is possible that these drugs were appropriately started during an acute illness in the ICU, most should have been discontinued at ICU or hospital discharge [48]. A common complication of critical illness is an increase in psychological symptoms, sleep cycle alterations, delirium and cognitive impairment, which is associated with increased prescription of specific medications, such as antipsychotics or benzodiazepines $[45,49,50]$. Despite the lack of reliable evidence supporting their use in the ICU, antipsychotics are routinely used in critically ill patients [51]. One potential drawback of antipsychotic use in the ICU is their continuation after the transition to other clinical settings, including discharge from the hospital [52]. Between 12 and $32 \%$ of older ICU survivors are discharged with an antipsychotic despite the fact that the majority of these patients were no longer delirious [48, 52-54]. Antipsychotics may even increase the risk of long-term mortality, especially in patients with dementia [55]. The use of these drugs has strongly been discouraged by the American Geriatrics Society and National Institute for Clinical Excellence because of their potential harmful effects [56].

Benzodiazepines and sedative hypnotics are commonly used to treat insomnia and agitation in older adults despite significant risks. Benzodiazepine administration was found to be an independent risk factor for delirium $[50,57]$. Clinicians should use alternatives known to reduce the daily number of benzodiazepines such as use of dexmedetomidine or propofol $[58,59]$.

Early detection of inappropriate medication prescriptions may prevent adverse drug events and improve geriatric care [60,61]. Different criteria are available to support a multidisciplinary team in medications evaluation such as the Beers Criteria for Potentially Inappropriate Medications Use in Older Adults [62]; the STOPP (Screening Tool of Older Persons' potentially inappropriate Prescriptions) and START (Screening Tool to Alert doctors to the Right Treatment) criteria [63].

\section{Triage: a multidisciplinary approach including the patient's wishes}

Intensive care unit triage is triggered by a formal or informal contact from a referring physician to a consultant physician. Both physicians, together with the patient 
and relatives, should consider the potential benefit from an ICU admission. If there is potential benefit considered, the patient should be proposed for admission to the ICU. If the benefit of an ICU admission is considered to be low, other options may be considered, from admission to a high-dependency unit or intermediate care to treatment on a regular or palliative care ward. It should be emphasized that there is often a mismatch between the clinicians' assessment and the patient's wishes [64]. Multidisciplinary collaboration in the decision-making process is strongly advocated [65]. More specifically for the very old, all healthcare providers who can help to improve the decision-making process for the benefit of the patient should be involved. Several important aspects should be considered by clinicians in the decision-making process: self-reflective and empowering leadership by physicians; practice and culture of open interdisciplinary reflection; culture of not avoiding end-of-life decisions; culture of mutual respect within the interdisciplinary team; active involvement of nurses in end-of-life care and decision making; active decision making by physicians; and practice and culture of ethical awareness.

Many patients are triaged by the emergency physician or the treating physician on the ward before the ICU consultation. This "hidden triage" is often not captured by studies focusing only on patients proposed for ICU admission [66]. However, even when proposed for ICU admission many old patients are declined. In a singlecenter study, $73.3 \%(132 / 180)$ of older patients referred for ICU admission were declined [67]. Similar data were recently found in a Norwegian multicenter study [68]. In the ICE-CUB 1 study [66], the ICU admission rate in critically ill older patients was only $14.4 \%$ after being triaged by the emergency physician and the intensivist. It is remarkable to notice that in these three studies, the longterm mortality was inferior to $100 \%$ in patients considered too sick for an ICU admission. On the other hand, the mortality was far from $0 \%$ in patients considered too well for an ICU admission (Table 2). These results suggest over- and under-utilization of ICUs. However, in the large multicenter observational Eldicus study $(n=6796$ patients), $82 \%$ of all patients were admitted, while nearly half of the patients $(49 \%)$ were $\geq 65$ years. Although a higher proportion of older patients were refused ICU admission, the survival benefit of admitted versus nonadmitted patient seemed to increase with age [69].

\section{Advanced directives should be available for older patients}

When an ICU admission is considered, clinicians must ensure that invasive procedures consistent with intensive care are in accordance with the patient's wishes. Patient physical dependency and previous documented decisions about end of life must be respected. However, very often realistic advanced healthcare directives have not been discussed before ICU admission. Whenever this is the situation, there are three possibilities:

- The patient has a normal cognition and is able to consent to care. Usually such conversation should be undertaken in the presence of the family or caregivers.

- Frequently, the old patients are unable to consent to care. In that case, physicians must discuss the intensity of care with the surrogate decision makers (family or caregivers). The main question is not what the surrogate decision maker think about and ICU admission, but what they know about the patient's wishes and how the patient would have responded to being admitted to intensive care.

- In emergency situations, there is no time for information retrieval from the surrogate decision makers and treatments are usually started without informed consent. In most countries, it is then possible to withdraw life-sustaining therapies (LSTs) when more information is available [70] (see small case story in Additional file 2).

\section{Level of treatment during the intensive care unit stay} When an older patient has been admitted to the ICU, the most appropriate treatment should be given. However, this does not necessarily mean maximal treatment. If, during the shared decision-making process, certain treatments such as invasive mechanical ventilation are thought to be disproportional to the chances of survival

Table 2 Results from three studies of pre ICU triage in very old patients

\begin{tabular}{lll}
\hline Patients triaged & $\begin{array}{l}\text { Hospital mortality } \\
(\%)\end{array}$ & $\begin{array}{l}\text { Long-term } \\
\text { mortality } \\
(\%)\end{array}$ \\
\hline Garrouste-Ortegas [67] & & At 1 year \\
Admission $(n=48)$ & 62.5 & 70.8 \\
Too sick $(n=79)$ & 70.8 & 87.3 \\
Too well $(n=51)$ & 17.6 & 47 \\
Boumendil $[109]$ & & At 6 months \\
Admission $(n=316)$ & 32.7 & 47.5 \\
Too sick $(n=821)$ & 58 & 81.1 \\
Too well $(1339)$ & 10.1 & 33.1 \\
Andersen [68] & & At 1 year \\
Admission $(n=250)$ & 44 & 60 \\
Too sick $(n=52)$ & 67.3 & 88.5 \\
Too well $(n=46)$ & 34.8 & 50 \\
\hline
\end{tabular}


or certain treatments are refused by the patient, these treatments should not be imposed upon the patient [64]. However, to give a patient a fair chance all other treatments should be applied. The ethical climate has also been found to have an impact on treatment-limitation decisions and time until death [71].

\section{Severity of the disease}

The severity scores have a poor discrimination in old patients [3] because they do not consider any geriatric assessment. A Canadian study developed a prediction tool for futility of ICU care although this study experienced extremely high observed mortality in the higher percentiles of risk [72].

\section{Withholding and withdrawing treatment}

Older patients often receive a lower level of treatment intensity than their younger counterparts. For example, the prevalence of limitations of life-sustaining therapies increased with age in surgical population [73-75]. In addition, decisions to withhold LST were made earlier during the ICU stay in comparison with younger patients $[13,76]$. In patients without improvement of their clinical situation, the therapeutic intensity level may no longer be in accordance with the patients' chances of long-term survival with acceptable quality of life, and a clinical decision might need to be made. Obviously, the timing of such a decision is arbitrary, but most agree that the older patient should be offered an "ICU trial" that lasts long enough to observe possible improvements [77]. Lifesustaining therapies limitation is not equivalent to endof-life decision. In the VIP1 study including more than 5000 patients $\geq 80$ years, the ICU and 30-day mortality rates were, respectively, $29 \%$ and $53 \%$ in the withholding group, and $82 \%$ and $93 \%$ in the withdrawing group [70]. In another study, ICU and hospital mortality rates were $56 \%$ and $69 \%$ despite a decision to withhold or withdraw LST [78].

For patients with withholding or withdrawing of LST, an important goal is to achieve the most comfortable death [78]. Family members reported that the "patient be comfortable and suffer as little as possible" was their most important value and "the belief that life should be preserved at all costs" was their least important value considered in making treatment decisions [79]. Mobile palliative care team could be very useful to help in the decision process and even to propose admission in a palliative unit.

In a recent study focusing on patients older than 80 , LST limitation was common (27.2\%) but with important regional differences [70]. In the Northern region, $45.2 \%$ had LST withdrawn compared with $12.8 \%$ in the Eastern region.
Apart from patient-related factors, other reasons to limit LSTs might play a role. Apparently, the ICU bed availability is associated with the timing of limitations of LSTs. Patients admitted in ICUs with a lower bed availability had a shorter time to do-not-resuscitate decisions and patients who had do-not-resuscitate decisions had shorter time to death [80]. In the VIP1 study, there was no relation between number of ICU beds and percentage of LST limitations. Percentage of LST limitations was higher in countries with high growth domestic product and was lower in more religious countries [70].

\section{Situations with specificities related to age}

Acute respiratory failure (ARF) was the most frequent reason for urgent ICU admission in the VIP1 study (25\%). Mechanical ventilation is responsible for a large percentage of ICU costs [81]. Experimental studies suggest that aging is also associated with an increased susceptibility to ventilator-induced lung injury [82]. The high mortality could be related to delays in diagnosis and treatment [83] since the presenting signs and symptoms may not be primarily respiratory such as delirium and cognitive impairment.

The incidence of acute respiratory distress syndrome (ARDS) increases markedly with age, which is largely determined by a higher incidence of sepsis in the very old [84]. Several studies have shown that age is independently associated with mortality in patients requiring mechanical ventilation and in ARDS [85, 86]. Age was also associated with longer duration of mechanical ventilation, ICU length of stay and mortality in ARDSNet database [87]. Long-term sequelae have been described after ARDS and are more frequent and severe in older patients. The ability to sustain spontaneous respiration after extubation is lower in patients older than 70 years, mainly due to the inability to clear tracheobronchial secretions and a higher incidence of nosocomial pneumonia [87].

Sepsis The incidence of sepsis increases with age. Additional risks include: subtle clinical presentations, institutionalization, use of invasive devices, multiple medications, reduced renal function and poor nutritional status. In the elderly population, sepsis is a major cause of morbidity and mortality, with almost $60 \%$ of septic patients being over 65 years of age [88].

Typically, younger patients with sepsis demonstrated fever, tachycardia and capillary vasodilatation. Older patients often exhibit few of these clinical symptoms but may present with an altered mental status, making early recognition rather challenging. Elderly patients often present with heart failure, arrhythmias and arterial hypertension. They have a lower cardiac compliance, whereas the renal perfusion is more cardiac flow dependent; thus, the management of fluid therapy is more sensitive. A 
predefined volume administration $(30 \mathrm{~mL} / \mathrm{kg})$ is inappropriate in most patients. Fluid bolus $(250 \mathrm{ml}$ at 5 - to 10-min intervals) and further evaluation to test whether goals are reached is a reasonable option.

Scheduled surgery should be considered apart from other stays Postoperative patients after planned surgery have a much better long-term survival than acute or emergency admissions [39, 89]. Obviously, patients after elective surgery represent a highly selected population of older patients. These patients tend to be younger, less frail and with a lower SOFA score on the first day of admission than patients after emergency admission [39]. In the VIP1 study, postoperative elective ICU admissions $(n=906)$ accounted for $17.7 \%$ of all admission and $24.6 \%$ of ICU stays shorter than $24 \mathrm{~h}$. Most of the patients were not frail, and the 1-month mortality was much lower than for acutely admitted patients [39]. In a study by Bagshaw, $72 \%$ of critically ill patients over 80 years admitted to the ICU were discharged home after elective surgery [13]. Long-term prognostic is much better for scheduled surgery compared to urgent admission [90].

No validated score is currently available to predict the need of perioperative ICU admission in the older patients. In a study of 275 patients aged 65 years or over undergoing intermediate- or high-risk elective surgery, a multidimensional frailty model (composed of the Charlson comorbidity index, dependence in activities of daily living, dementia, risk of delirium, short mid-arm circumference and malnutrition) predicted mortality rates more accurately than the ASA classification (84\% sensitivity and 69\% specificity). High-risk patients (defined as a multidimensional frailty score $>5$ ) showed increased postoperative mortality risk and longer hospital LOS [91]. In contrast, the urgent surgical patients requiring ICU admission are as severely ill as medical patients need more organ support and have longer hospital LOS (see Additional file 3).

\section{Timing and location of ICU discharge are keys elements for the outcome}

Risk factors for in-hospital mortality after ICU discharge include age, comorbidities and severity of illness [92], in addition to organizational factors, such as discharge time and the availability of step-down facilities [93, 94]. Older patients discharged from the ICU are particularly vulnerable to poor handovers due to their complicated physiology and the substantial decrease in monitoring when these patients are transferred from the ICU to a general ward $[95,96]$. However, studies have failed to show an impact of discharge protocol on hospital mortality [96], although none tested the discharge location as a potential variable of interest [95]. Except for acute geriatric units (AGUs), geriatric expertise is usually not available on a regular basis in other wards. To illustrate this, of the participants of the VIP1 study [39], one-third disagreed that a consultation of a geriatrician should be sought when deciding to discharge an elderly patient [97]. Yet, due to their expertise in the field of multimorbidities and acute stress in older patients, geriatricians make a more comprehensive assessment of old patients that may lead to better care and orientation decisions in these patients. Including a geriatrician in shared decision making for old critically ill older patients may improve their outcome. However, no large-scale study supports this hypothesis.

In a cohort of 1283 French patients of $\geq 75$ years, $40.3 \%$ of the patients were transferred to a geriatric unit after an emergency department visit [98]. Four factors were related to admission to a geriatrics unit: cognitive disorder, "failure to thrive" syndrome, depression or loss of Activities of Daily Living. However, considerable nationwide variations were observed underlying the need to clarify and reinforce this discipline in the emergency healthcare system. A small-scale, single-center study illustrates the beneficial effect of geriatric intervention on the functional dependency of 45 older patients after discharge from a medical/surgical ICU [99]. Although physical function was usually recovered rapidly, the degree of recovery depended on the patient's previous physical dependency.

Inclusion of geriatric consultations has proven valuable in other areas of medicine. Studies have documented that for postoperative older patients, mainly after hip fracture, geriatric unit admission offers a benefit as compared to surgical unit admission [100]. Postoperative admission to a dedicated geriatric unit reduced both re-admission rate and 6-month mortality. After adjustment for comorbidities, risk ratio of death at 6 months was of $0.43(95 \% \mathrm{CI}$ $0.25-0.73, P=0.002)$ [101].

\section{Long-term outcomes are the best criteria to judge appropriateness of decision (admission, LST during the ICU stay)}

Predicting long-term survival and quality of life is difficult [102]. The outcome of an older patient admitted to the ICU is dependent on: previous comorbidities, diagnosis at admission, severity of the acute illness at the time, course of the disease during the ICU stay, limitations of LSTs and age itself. There is a confounding factor in the data reporting the long-term survival and quality of life, since patients might have died of limitation of LST.

The quality of life and recovery has been shown to be poorer in elderly patients ventilated for more than 7 days, with higher proportion of debilities [103]. Similar finding 
were reported for neurocognitive problems such as PTSD or cognitive impairment [25].

A higher proportion of older patients will be expected to wish limitation of care when having a critical illness. Outcome in terms of survival (Fig. 3), physical function at 1 year [104] and quality of life [105] in elderly ICU survivors are often reported to be significantly lower than in their younger counterparts (Table 3).

Older patients surviving the ICU often suffer from sequels, including increased long-term mortality [89], poor quality-adjusted survival [107], cognitive impairment and functional disability $[25,106-108]$. Many of these events occur beyond the scope of intensive care. However, it is of outmost importance to try to predict the functional outcome (Table 3 ) of this very elderly patient group [102] as their focus is less on "longevity" but more on "quality of life." The very old ICU patient is at risk of complications resulting from heavy sedation, prolonged ventilation, immobilization, insufficient nutrition, etc. Ultimately this leads to functional decline. In a prospective study, including 2646 older patients, among the survivors after 6 months only one-third was independent for all activities listed in Katz's scale, while $16.2 \%$ were unable to perform at least one activity that they had been able to perform at the time of the ED visit [109]. The pessimistic conclusion was that, at 6 months after the ED visit, $63 \%$ of patients had either died or experienced functional deterioration. This is corroborated by a recent Canadian study in older patients with ICU LOS of more than $24 \mathrm{~h}$. The survivors reported significantly worse physical functioning after 3, 6 and 12 months compared with age- and gender-matched controls [104]. In the ICE-CUB 2 study, including 3036 patients (mean age 85 years), the ADL scale decreased in at least one domain in $64 \%$ of the patients at 6 months [110]. However, other studies find that only $28-37 \%$ did not restore their previous functional dependency, evaluated on activity of daily living at 3, 6 and 12 months [111, 112]. At 12 months, 50\% of survival patients recovered their previous ADL, IALD and physical capacities [104, 113]. Furthermore, 72-77\% of patients return at home after ICU [13, 112, 114]. It is interesting to point at the lack of data concerning comparison of functional dependency recovery between "young" and "old" patients, while almost 25\% of "young" patients do not restore their functional dependency after ICU [115].

A decline in functional performance is accompanied by a decrease in health-related quality of life (HRQoL) as demonstrated in the ICE-CUB 2 study [110]. In an UK study [116], the physical and the mental component of HRQoL short-form questionnaire (SF36) did not improve from 6 to 12 months after ICU discharge. In a Scandinavian study, the HRQoL was lower for the very elderly than for younger patients, although $97 \%$ of the elderly survivors lived at home and $88 \%$ of them considered their QoL satisfactory or good after hospital discharge [117]. Indeed, other studies show that the long-term HRQoL appears to be similar to age-matched populations [67, $112,114,118]$. Ultimately, in the worse scenario the patients are at risk of loss of function, inability to return home, requirement for a nursing home and/or remain bed bound for the rest of their lives.

\section{Quality-adjusted life years}

Kaarlola et al. [117] showed that the QALYs derived from ICU admission of patients 80 years or over would be a median of 4.1 years, in the 65- to 79-year-old group it would be 10.2 years and in patients less than 65 years it would be 22 years.

\section{House caregivers}

One of the most neglected groups is the caregivers of the very old ICU survivors. After hospital discharge, many patients still need help in many activities of daily living, often provided by family members or partners. This radically changes their role from "loved one" to "caregiver." However, many of the family members of surviving older

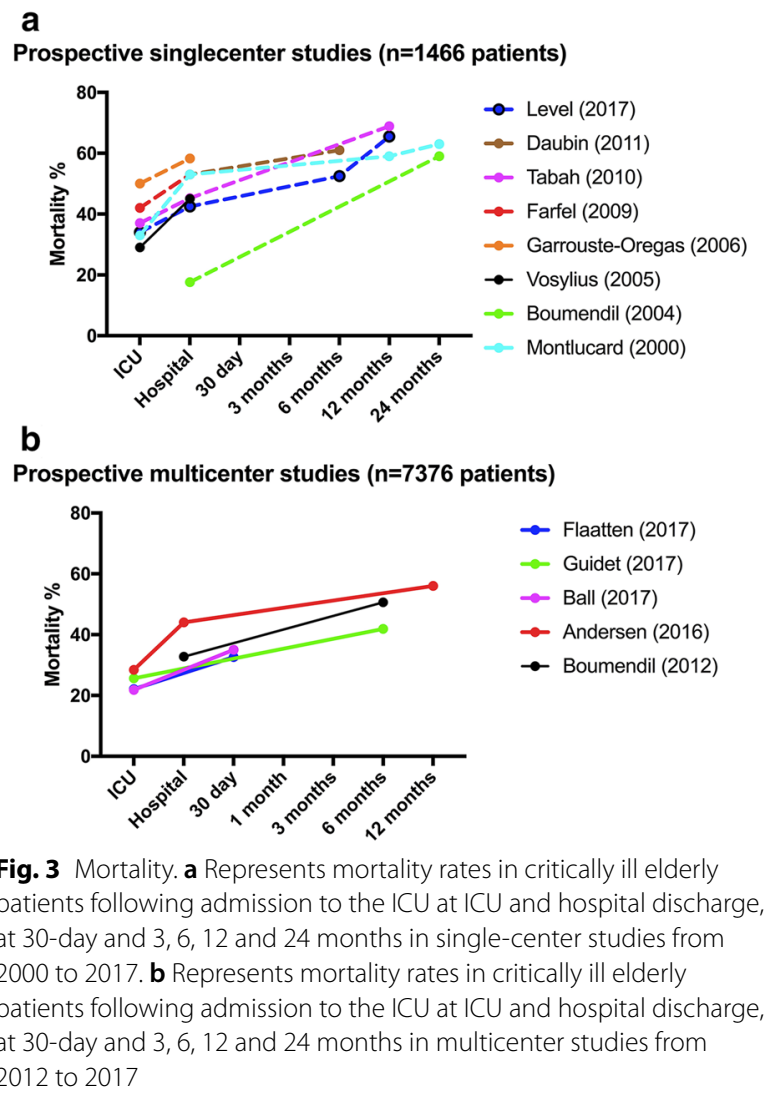


Table 3 Long-term functional outcome

\begin{tabular}{|c|c|c|c|c|c|c|}
\hline References & Tool & Design & Age-group & Patient followed & Main results & $\begin{array}{l}\text { Comparison } \\
\text { with baseline data } \\
\text { (ICU admission) }\end{array}$ \\
\hline Kass [123] & ADL & $\begin{array}{l}\text { Prospective } \\
\text { and retro- } \\
\text { spective }\end{array}$ & $>80$ years & 38/105 (36.1\%) & $\begin{array}{l}\text { Nonsignificant decline of ADL score at } \\
1 \text { year }\end{array}$ & Yes \\
\hline Chelluri [124] & ADL & Prospective & $\begin{array}{l}>75 \text { years, } \\
\quad 65-74 \text { years })\end{array}$ & $\begin{array}{l}96 \\
18 / 54(33 \%) \\
20 / 43(46.5 \%)\end{array}$ & $\begin{array}{l}\text { No difference between two age-groups } \\
\text { at } 1,6,12 \text { months }\end{array}$ & $\begin{array}{l}\text { Yes } \\
\text { Method? }\end{array}$ \\
\hline Broslawski [125] & $\begin{array}{l}\text { ADL, } \\
\text { IADL, } \\
\text { GDS }\end{array}$ & Prospective & $>70$ years & $27 / 45(60 \%)$ & $\begin{array}{l}\text { Changes at } 6 \text { months related to ICU LOS } \\
\text { and severity but not to age }\end{array}$ & $\begin{array}{l}\text { Yes } \\
\text { Method? }\end{array}$ \\
\hline Montuclard [126] & $\mathrm{ADL}$ & Retrospective & $\begin{array}{l}70 \text { years with } \\
30 \text { days of } \\
\text { MV }\end{array}$ & $30 / 75(40 \%)$ & $\begin{array}{l}\text { Decrease in all domains except feeding } \\
\text { at } 6 \text { months }\end{array}$ & $\begin{array}{l}\text { Retrospective estima- } \\
\text { tion by the patient }\end{array}$ \\
\hline Udekwu [127] & ADL & Retrospective & $>70$ years & $342 / 672(50.8 \%)$ & $\begin{array}{l}\text { At } 21 \text { months, significant decrease in } \\
\text { ADL with more dependent patients }\end{array}$ & $\begin{array}{l}\text { Yes } \\
\text { Method? }\end{array}$ \\
\hline $\begin{array}{l}\text { Garrouste-Orgeas } \\
\text { [37] }\end{array}$ & ADL & Prospective & $\geq 80$ years & $9 / 48(18 \%)$ & No change & $\begin{array}{l}\text { Retrospective estima- } \\
\text { tion by the patient }\end{array}$ \\
\hline Kaarlola [119] & $\begin{array}{l}\text { EQ-5D } \\
\text { SF-36 }\end{array}$ & $\begin{array}{l}\text { Retrospective } \\
\text { (in survivors) }\end{array}$ & $\begin{array}{l}65-69 \text { years } \\
70-74 \text { years } \\
75-79 \text { years } \\
80-94 \text { years }\end{array}$ & $\begin{array}{l}114 \\
117 \\
91 \\
50\end{array}$ & $\begin{array}{l}\text { More than } 50 \% \text { assessed their overall } \\
\text { health status as satisfactory. Largest \% } \\
\text { in those } \geq 80\end{array}$ & No \\
\hline Tabah [128] & $\mathrm{ADL}$ & Prospective & $\geq 80$ years & 23/106 (21\%) & $\begin{array}{l}\text { No change } \\
74 \% \text { of patients were fully independent }\end{array}$ & $\begin{array}{l}\text { Prospective estima- } \\
\text { tion by the patient } \\
\text { or relatives }\end{array}$ \\
\hline Boumendil [109] & ADL & Prospective & $\geq 80$ years & $162 / 329$ & $\begin{array}{l}\text { At } 6 \text { months } \\
16.2 \% \text { were unable to perform at least } \\
\text { one activity that they had been able to } \\
\text { perform at the time of the ED visit }\end{array}$ & $\begin{array}{l}\text { Prospective estima- } \\
\text { tion by the patient } \\
\text { or relatives }\end{array}$ \\
\hline Andersen [129] & EQ-5D & Retrospective & $\geq 80$ & $58 / 395$ & $\begin{array}{l}\text { HRQOL comparable with a comparison } \\
\text { group (1 year) }\end{array}$ & \\
\hline Andersen 2017 [68] & EQ-5D & Prospective & $\geq 80$ & $62 / 250$ & $\begin{array}{l}\text { Lower HRQOL than a comparison group } \\
\text { (1 year) }\end{array}$ & $\begin{array}{l}\text { Compared with a age } \\
\text { and gender refer- } \\
\text { ence population } \\
n=179\end{array}$ \\
\hline Heyland [104] & $\begin{array}{l}\text { SF-36 } \\
\text { (physi- } \\
\text { cal } \\
\text { func- } \\
\text { tion) }\end{array}$ & Prospective & $\geq 80$ & $505 / 610$ & $\begin{array}{l}50 \% \text { dead and } 26 \% \text { achieved physical } \\
\text { recovery at } 12 \text { months }\end{array}$ & $\begin{array}{l}\text { PF compared with } \\
\text { baseline values at } \\
\text { admission }\end{array}$ \\
\hline Level 2017 [130] & $\begin{array}{l}\text { ADL, } \\
\text { Bar- } \\
\text { thel } \\
\text { index }\end{array}$ & Prospective & $\geq 75$ & $65 / 188$ & $\begin{array}{l}83 \% \text { of } 1 \text {-year survivors lived in their own } \\
\text { home }\end{array}$ & $\begin{array}{l}\text { ADL compared with } \\
\text { baseline at admis- } \\
\text { sion }\end{array}$ \\
\hline Guidet [110] & ADL & Prospective & $\geq 75$ years & $1528 / 3036$ & $\begin{array}{l}\text { Selection criteria: preserved baseline } \\
\text { ADL (median 6) } \\
\text { At } 6 \text { months, decrease in ADL of } 0.5 \\
\text { points }\end{array}$ & $\begin{array}{l}\text { Prospective estima- } \\
\text { tion by the patient } \\
\text { or relatives }\end{array}$ \\
\hline
\end{tabular}

critically ill patients are old themselves. As such, they can be considered as "the second victim" and may suffer from the same cognitive and even functional decline as the ICU survivors. For example, in a general ICU population $67 \%$ of the caregivers reported depressive symptoms, which remained in $43 \%$ at a follow-up of 1 year [119]. Variables that were significantly associated with worse mental health outcomes in caregivers were greater effect of patient care on other activities, less social support, and therefore less sense of control over life. Post-traumatic stress disorder (PTSD) and strain are seen in $21 \%$ of the caregivers [120]. A randomized trial, where caregivers provided respiratory physiotherapy at home, showed improvement of the cardiorespiratory status of the patients and their HRQoL (as measured with the EuroQoL 5D methodology) [121, 122]. While the majority 
of the above-mentioned studies were not specifically designed for the very elderly patient group, it seems logical that the perceived strain, depressive symptoms and HRQoL will also translate to this group of caregivers.

\section{Conclusions and algorithm}

In this review, we have given an up-to-date review of the present knowledge about caring for the older ICU patients. This specific group will in the future certainly

\section{Table 4 Key messages and unresolved issues}

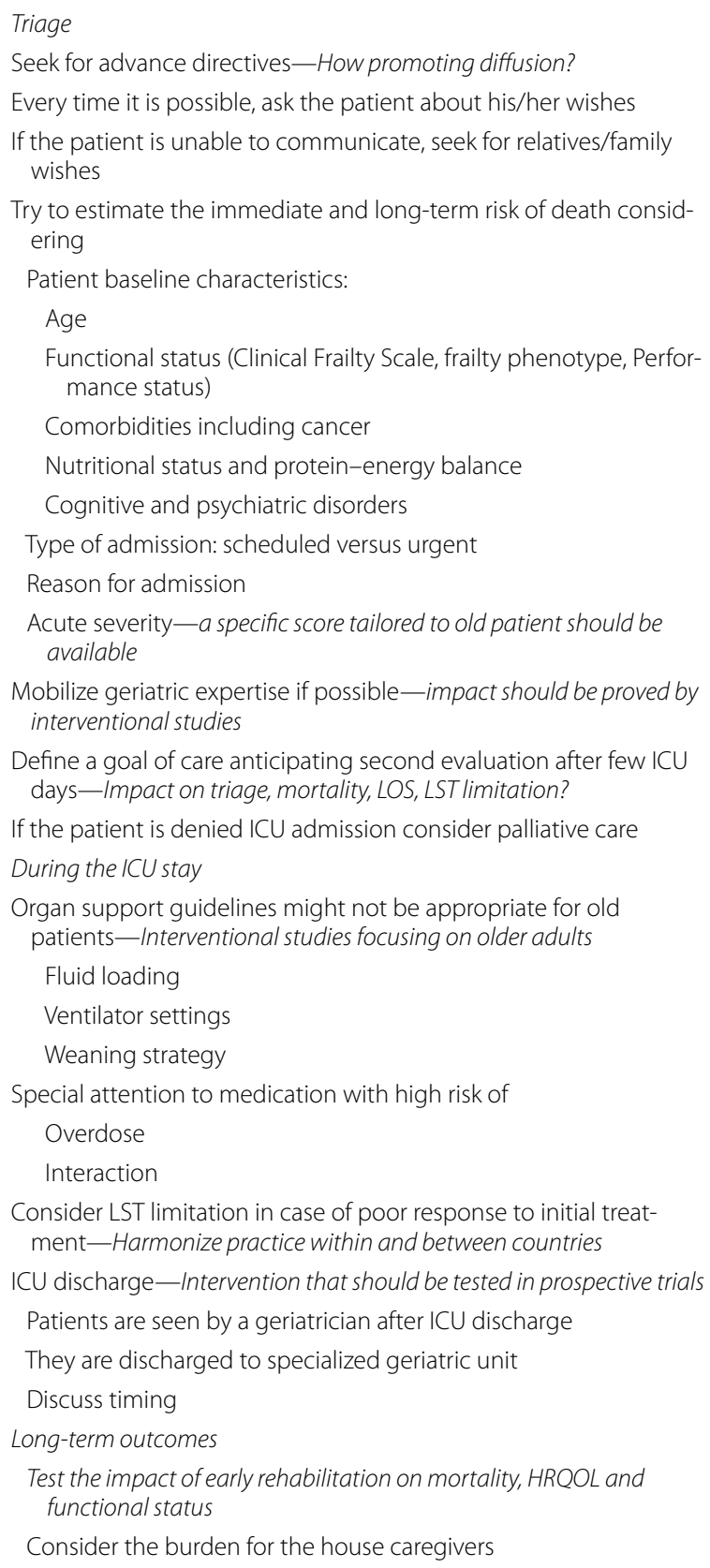

claim their rights to receive high-quality health care including intensive care. The outcome of the very old has improved over the past decades but remains poorer than for younger patients. Several factors account for this high mortality and more related to underlying disease than age by itself. Advanced care planning will become more and more important in the future because of the increasing number of admission in combination with technological innovation. We summarized in a table, the keys elements that should be considered when deciding to admit a patient older than 80 in ICU (Table 4). There are still many unresolved questions [3] (Table 4), and it is important to get answers to these unresolved issues before the huge «age-tsunami» reaches the hospitals within $10-15$ years.

\section{Additional files}

Additional file 1. Clinical Frailty Scale (with permission).

Additional file 2. Case vignette.

Additional file 3. Outcomes.

\begin{abstract}
Abbreviations
ICU: Intensive care unit; ADL: Activities of Daily Living; IADL: Instrumental Activities of Daily Living; CFS: Clinical Frailty Scale; ICE-CUB: Intensive Care for Elderly-CUB Rea Network; APACHE: Acute Physiology and Chronic Health Evaluation; SAPS: Simplified Acute Physiology Score; SOFA: Sequential Organ Failure Assessment; LST: life-sustaining treatments; ARF: acute respiratory failure; ARDS: acute respiratory distress syndrome; STOPP: Screening Tool of Older Persons' Potentially Inappropriate Prescriptions; START: Screening Tool to Alert doctors to the Right Treatment; VIP: Very elderly intensive care patient; ED: emergency department; HRQoL: health-related quality of life; QALYS: qualityadjusted life years; PTSD: post-traumatic stress disorder.
\end{abstract}

\section{Authors' contributions}

All authors contributed to the writing of the manuscript and approved the final version.

\begin{abstract}
Author details
${ }^{1}$ Assistance Publique - Hôpitaux de Paris (AP-HP), Service de Réanimation Médicale, Hôpital Saint-Antoine, 184 rue du Faubourg Saint-Antoine, 75012 Paris, France. ${ }^{2}$ Sorbonne Universités, Université Pierre et Marie Curie - Paris 06, Paris, France. ${ }^{3}$ INSERM, UMR_S 1136, Institute Pierre Louis d'Épidémiologie et de Santé Publique, 75013 Paris, France. ${ }^{4}$ Assistance Publique - Hôpitaux de Paris (AP-HP), Service de gériatrie, Hôpital Pitié salpêtrière, 75013 Paris, France. ${ }^{5}$ Department of Intensive Care, University Medical Center Utrecht, University Utrecht, Utrecht, The Netherlands. ${ }^{6}$ Department of Rehabilitation Hospital Ancelle di Cremona, Cremona, Italy. ${ }^{7}$ Geriatric Research Group, Brescia, Italy. ${ }^{8}$ Division of Critical Care Medicine, Department of Anesthesiology and Critical Care Medicine, Université Laval, Québec City, QC, Canada. ${ }^{9}$ Centre de recherche du CHU de Québec - Université Laval, Population Health and Optimal Health Practices Research Unit (Trauma - Emergency - Critical Care Medicine), Université Laval, Québec City, QC, Canada. ${ }^{10}$ Department of Intensive Care Medecine, CIBER EnfermedadesRespiratorias, Corporacion Sanitaria Universitaria Parc Tauli, Autonomous University of Barcelona, Sabadell, Spain. ${ }^{11}$ Department of Anaesthesia and Intensive Care, Haukeland University Hospital, Bergen, Norway. ${ }^{12}$ Department of Clinical Medicine, University of Bergen, Bergen, Norway.
\end{abstract}

Competing interests

The authors declare that they have no competing interests. 
Availability of data and materials

Not applicable.

\section{Consent for publication}

Not applicable.

\section{Ethics approval and consent to participate}

Not applicable.

\section{Funding}

No funding for this review.

\section{Publisher's Note}

Springer Nature remains neutral with regard to jurisdictional claims in published maps and institutional affiliations.

Received: 6 July 2018 Accepted: 14 November 2018 Published online: 26 November 2018

\section{References}

1. Flaatten $\mathrm{H}$. Intensive care in the very old: are we prepared? Acta Anaesthesiol Scand. 2007:51(5):519-21.

2. Laake JH, Dybwik K, Flaatten HK, Fonneland I-L, Kvåle R, Strand K. Impact of the post-World War II generation on intensive care needs in Norway. Acta Anaesthesiol Scand. 2010;54(4):479-84.

3. Flaatten $\mathrm{H}$, de Lange DW, Artigas A, Bin D, Moreno R, Christensen $\mathrm{S}$, et al. The status of intensive care medicine research and a future agenda for very old patients in the ICU. Intensive Care Med. 2017:43(9):1319-28.

4. Chin-Yee N, D'Egidio G, Thavorn K, Heyland D, Kyeremanteng K. Cost analysis of the very elderly admitted to intensive care units. Crit Care. 2017;21(1):109.

5. Angus DC. Admitting elderly patients to the intensive care unit-is it the right decision? JAMA. 2017;318(15):1443-4.

6. Nguyen $Y-L$, Angus DC, Boumendil A, Guidet B. The challenge of admitting the very elderly to intensive care. Ann Intensive Care. 2011;1(1):29.

7. Leblanc G, Boumendil A, Guidet B. Ten things to know about critically ill elderly patients. Intensive Care Med. 2017:43(2):217-9.

8. Hennessy D, Juzwishin K, Yergens D, Noseworthy T, Doig C. Outcomes of elderly survivors of intensive care: a review of the literature. Chest. 2005;127(5):1764-74.

9. Barnett K, Mercer SW, Norbury M, Watt G, Wyke S, Guthrie B. Epidemiology of multimorbidity and implications for health care, research, and medical education: a cross-sectional study. Lancet. 2012:380(9836):37-43.

10. Salive ME. Multimorbidity in older adults. Epidemiol Rev. 2013;35:75-83.

11. Menotti A, Mulder I, Nissinen A, Giampaoli S, Feskens EJ, Kromhout D. Prevalence of morbidity and multimorbidity in elderly male populations and their impact on 10-year all-cause mortality: the FINE study (Finland, Italy, Netherlands, Elderly). J Clin Epidemiol. 2001;54(7):680-6.

12. Wolff JL, Starfield B, Anderson G. Prevalence, expenditures, and complications of multiple chronic conditions in the elderly. Arch Intern Med. 2002;162(20):2269-76

13. Bagshaw SM, Webb SAR, Delaney A, George C, Pilcher D, Hart GK, et al. Very old patients admitted to intensive care in Australia and New Zealand: a multi-centre cohort analysis. Crit Care. 2009;13(2):R45.

14. Zampieri FG, Colombari F. The impact of performance status and comorbidities on the short-term prognosis of very elderly patients admitted to the ICU. BMC Anesthesiol. 2014;14:59.

15. Stavem K, Hoel H, Skjaker SA, Haagensen R. Charlson comorbidity index derived from chart review or administrative data: agreement and prediction of mortality in intensive care patients. Clin Epidemiol. 2017;9:311-20.

16. Charlson ME, Pompei P, Ales KL, MacKenzie CR. A new method of classifying prognostic comorbidity in longitudinal studies: development and validation. J Chronic Dis. 1987:40(5):373-83.

17. Marik PE. Management of the critically ill geriatric patient. Crit Care Med. 2006:34(9 Suppl):S176-82.
18. Zeleznik J. Normative aging of the respiratory system. Clin Geriatr Med. 2003;19(1):1-18.

19. Hughes VA, Frontera WR, Roubenoff R, Evans WJ, Singh MAF. Longitudinal changes in body composition in older men and women: role of body weight change and physical activity. Am J Clin Nutr. 2002;76(2):473-81.

20. Marzetti E, Leeuwenburgh C. Skeletal muscle apoptosis, sarcopenia and frailty at old age. Exp Gerontol. 2006;41(12):1234-8.

21. Abd Aziz NAS, Teng NIMF, Abdul Hamid MR, Ismail NH. Assessing the nutritional status of hospitalized elderly. Clin Interv Aging. 2017;12:1615-25.

22. Neumann SA, Miller MD, Daniels L, Crotty M. Nutritional status and clinical outcomes of older patients in rehabilitation. J Hum Nutr Diet. 2005:18:129-36.

23. Walston J, Hadley EC, Ferrucci L, Guralnik JM, Newman AB, Studenski SA, et al. Research agenda for frailty in older adults: toward a better understanding of physiology and etiology: summary from the American Geriatrics Society/National Institute on Aging Research Conference on Frailty in Older Adults. J Am Geriatr Soc. 2006;54(6):991-1001.

24. Thibault R, Pichard C. Nutrition and clinical outcome in intensive care patients. Curr Opin Clin Nutr Metab Care. 2010;13(2):177-83.

25. Pandharipande PP, Girard TD, Jackson JC, Morandi A, Thompson JL, Pun BT, et al. Long-term cognitive impairment after critical illness. N Engl J Med. 2013;369(14):1306-16.

26. Pisani MA, Inouye SK, McNicoll L, Redlich CA. Screening for preexisting cognitive impairment in older intensive care unit patients: use of proxy assessment. J Am Geriatr Soc. 2003:51(5):689-93.

27. Elie M, Cole MG, Primeau FJ, Bellavance F. Delirium risk factors in elderly hospitalized patients. J Gen Intern Med. 1998;13(3):204-12.

28. Schor JD, Levkoff SE, Lipsitz LA, Reilly CH, Cleary PD, Rowe JW, et al. Risk factors for delirium in hospitalized elderly. JAMA. 1992;267(6):827-31.

29. Ouimet S, Kavanagh BP, Gottfried SB, Skrobik Y. Incidence, risk factors and consequences of ICU delirium. Intensive Care Med. 2007;33(1):66-73.

30. Katz S, Akpom CA. 12. Index of ADL. Med Care. 1976;14(5 Suppl):116-8.

31. Lawton MP, Brody EM. Assessment of older people: self-maintaining and instrumental activities of daily living. The Gerontologist. 1969:9(3):179-86

32. Barberger-Gateau P, Commenges D, Gagnon M, Letenneur L, Sauvel C, Dartigues JF. Instrumental activities of daily living as a screening tool for cognitive impairment and dementia in elderly community dwellers. J Am Geriatr Soc. 1992:40(11):1129-34.

33. Muscedere J, Waters B, Varambally A, Bagshaw SM, Boyd JG, Maslove D, et al. The impact of frailty on intensive care unit outcomes: a systematic review and meta-analysis. Intensive Care Med. 2017;43(8):1105-22.

34. Clegg A, Young J, Iliffe S, Rikkert MO, Rockwood K. Frailty in elderly people. Lancet. 2013;381(9868):752-62.

35. Cruz-Jentoft AJ, Kiesswetter E, Drey M, Sieber CC. Nutrition, frailty, and sarcopenia. Aging Clin Exp Res. 2017;29(1):43-8.

36. Rockwood K, Song X, MacKnight C, Bergman H, Hogan DB, McDowel I, et al. A global clinical measure of fitness and frailty in elderly people. CMAJ. 2005;173(5):489-95.

37. http:/geriatricresearch medicinedal.ca/clinical frailty scale.htm.

38. Fried LP, Ferrucci L, Darer J, Williamson JD, Anderson G. Untangling the concepts of disability, frailty, and comorbidity: implications for improved targeting and care. J Gerontol A Biol Sci Med Sci. 2004;59(3):255-63.

39. Flaatten $\mathrm{H}$, De Lange DW, Morandi A, Andersen FH, Artigas A, Bertolini $G$, et al. The impact of frailty on ICU and 30-day mortality and the level of care in very elderly patients ( $\geq 80$ years). Intensive Care Med. 2017;43(12):1820-8

40. Montamat SC, Cusack BJ, Vestal RE. Management of drug therapy in the elderly. N Engl J Med. 1989;321(5):303-9.

41. Greenblatt DJ, Sellers EM, Shader RI. Drug therapy: drug disposition in old age. N Engl J Med. 1982;306(18):1081-8.

42. Tosato M, Landi F, Martone AM, Cherubini A, Corsonello A, Volpato $\mathrm{S}$, et al. Potentially inappropriate drug use among hospitalised older adults: results from the CRIME study. Age Ageing. 2014;43(6):767-73.

43. Morandi A, Vasilevskis E, Pandharipande PP, Girard TD, Solberg LM, Neal EB, et al. Inappropriate medication prescriptions in elderly adults 
surviving an intensive care unit hospitalization. J Am Geriatr Soc. 2013;61(7):1128-34.

44. Lau DT, Kasper JD, Potter DEB, Lyles A, Bennett RG. Hospitalization and death associated with potentially inappropriate medication prescriptions among elderly nursing home residents. Arch Intern Med. 2005; 165(1):68-74.

45. Wright RM, Roumani YF, Boudreau R, Newman AB, Ruby CM, Studensk SA, et al. Effect of central nervous system medication use on decline in cognition in community-dwelling older adults: findings from the Health, Aging And Body Composition Study. J Am Geriatr Soc. 2009:57(2):243-50.

46. Page RL, Linnebur SA, Bryant LL, Ruscin JM. Inappropriate prescribing in the hospitalized elderly patient: defining the problem, evaluation tools, and possible solutions. Clin Interv Aging. 2010;5:75-87.

47. Scales DC, Fischer HD, Li P, Bierman AS, Fernandes O, Mamdani M, et al. Unintentional continuation of medications intended for acute illness after hospital discharge: a population-based cohort study. J Gen Intern Med. 2016;31(2):196-202.

48. Morandi A, Vasilevskis EE, Pandharipande PP, Girard TD, Solberg LM, Neal EB, et al. Inappropriate medications in elderly ICU survivors: where to intervene? Arch Intern Med. 2011;171(11):1032-4.

49. Ehlenbach WJ, Hough CL, Crane PK, Haneuse SJPA, Carson SS, Curtis JR, et al. Association between acute care and critical illness hospitalization and cognitive function in older adults. JAMA. 2010;303(8):763-70.

50. Pandharipande P, Shintani A, Peterson J, Pun BT, Wilkinson GR, Dittus RS, et al. Lorazepam is an independent risk factor for transitioning to delirium in intensive care unit patients. Anesthesiology. 2006;104(1):21-6.

51. Swan JT, Fitousis K, Hall JB, Todd SR, Turner KL. Antipsychotic use and diagnosis of delirium in the intensive care unit. Crit Care. 2012;16(3):R84

52. Tomichek JE, Stollings JL, Pandharipande PP, Chandrasekhar R, Ely EW, Girard TD. Antipsychotic prescribing patterns during and after critical illness: a prospective cohort study. Crit Care. 2016;20(1):378.

53. Jasiak KD, Middleton EA, Camamo JM, Erstad BL, Snyder LS, Huckleberry YC. Evaluation of discontinuation of atypical antipsychotics prescribed for ICU delirium. J Pharm Pract. 2013:26(3):253-6.

54. Kram BL, Kram SJ, Brooks KR. Implications of atypical antipsychotic prescribing in the intensive care unit. J Crit Care. 2015;30(4):814-8.

55. van Eijk MMJ, Roes KCB, Honing MLH, Kuiper MA, Karakus A, van der Jagt $M$, et al. Effect of rivastigmine as an adjunct to usual care with haloperidol on duration of delirium and mortality in critically ill patients: a multicentre, double-blind, placebo-controlled randomised trial. Lancet. 2010:376(9755):1829-37.

56. AGS Choosing Wisely Workgroup. American Geriatrics Society identifies five things that healthcare providers and patients should question. J Am Geriatr Soc. 2013;61(4):622-31.

57. Zaal IJ, Devlin JW, Hazelbag M, Klein Klouwenberg PMC, van der Kooi AW, Ong DSY, et al. Benzodiazepine-associated delirium in critically ill adults. Intensive Care Med. 2015;41(12):2130-7.

58. Barr J, Fraser GL, Puntillo K, Ely EW, Gélinas C, Dasta JF, et al. Clinical practice guidelines for the management of pain, agitation, and delirium in adult patients in the intensive care unit. Crit Care Med. 2013;41(1):263-306

59. Riker RR, Shehabi Y, Bokesch PM, Ceraso D, Wisemandle W, Koura F, et al. Dexmedetomidine vs midazolam for sedation of critically ill patients: a randomized trial. JAMA. 2009;301(5):489-99.

60. Garfinkel D, Mangin D. Feasibility study of a systematic approach for discontinuation of multiple medications in older adults: addressing polypharmacy. Arch Intern Med. 2010;170(18):1648-54.

61. O'Mahony D, Gallagher PF. Inappropriate prescribing in the older population: need for new criteria. Age Ageing. 2008;37(2):138-41.

62. Blanco-Reina E, Ariza-Zafra G, Ocaña-Riola R, León-Ortiz M. 2012 American Geriatrics Society Beers criteria: enhanced applicability for detecting potentially inappropriate medications in European older adults? A comparison with the Screening Tool of Older Person's Potentially Inappropriate Prescriptions. J Am Geriatr Soc. 2014;62(7):1217-23.

63. Hill-Taylor B, Sketris I, Hayden J, Byrne S, O'Sullivan D, Christie R. Application of the STOPP/START criteria: a systematic review of the prevalence of potentially inappropriate prescribing in older adults, and evidence of clinical, humanistic and economic impact. J Clin Pharm Ther. 2013:38(5):360-72.
64. Philippart F, Vesin A, Bruel C, Kpodji A, Durand-Gasselin B, Garçon P, et al. The ETHICA study (part I): elderly's thoughts about intensive care unit admission for life-sustaining treatments. Intensive Care Med. 2013;39(9):1565-73.

65. Van den Bulcke B, Piers R, Jensen HI, Malmgren J, Metaxa V, Reyners AK, et al. Ethical decision-making climate in the ICU: theoretical framework and validation of a self-assessment tool. BMJ Qual Saf. 2018;27(10):781-9.

66. Garrouste-Orgeas M, Boumendil A, Pateron D, Aergerter P, Somme $D$, Simon T, et al. Selection of intensive care unit admission criteria for patients aged 80 years and over and compliance of emergency and intensive care unit physicians with the selected criteria: an observational, multicenter, prospective study. Crit Care Med. 2009:37(11):2919-28.

67. Garrouste-Orgeas M, Timsit J-F, Montuclard L, Colvez A, Gattolliat O, Philippart F, et al. Decision-making process, outcome, and 1-year quality of life of octogenarians referred for intensive care unit admission. Intensive Care Med. 2006;32(7):1045-51.

68. Andersen FH, Flaatten H, Klepstad P, Follestad T, Strand K, Krüger AJ, et al. Long-term outcomes after ICU admission triage in octogenarians. Crit Care Med. 2017;45(4):e363-71.

69. Sprung CL, Artigas A, Kesecioglu J, Pezzi A, Wiis J, Pirracchio R, et al. The Eldicus prospective, observational study of triage decision making in European intensive care units. Part II: intensive care benefit for the elderly. Crit Care Med. 2012;40(1):132-8.

70. Guidet B, Flaatten H, Boumendil A, Morandi A, Andersen FH, Artigas $A$, et al. Withholding or withdrawing of life-sustaining therapy in older adults ( $\geq 80$ years) admitted to the intensive care unit. Intensive Care Med. 2018:44(7):1027-38.

71. Benoit DD, Jensen HI, Malmgren J, Metaxa V, Reyners AK, Darmon $M$, et al. Outcome in patients perceived as receiving excessive care across different ethical climates: a prospective study in 68 intensive care units in Europe and the USA. Intensive Care Med. 2018;44(7):1039-49.

72. Ball IM, Bagshaw SM, Burns KEA, Cook DJ, Day AG, Dodek PM, et al. A clinical prediction tool for hospital mortality in critically ill elderly patients. J Crit Care. 2016:35:206-12.

73. Brandberg C, Blomqvist $H$, Jirwe M. What is the importance of age on treatment of the elderly in the intensive care unit? Acta Anaesthesiol Scand. 2013:57(6):698-703.

74. Hamel MB, Henderson WG, Khuri SF, Daley J. Surgical outcomes for patients aged 80 and older: morbidity and mortality from major noncardiac surgery. J Am Geriatr Soc. 2005;53(3):424-9.

75. Roger C, Morel J, Molinari N, Orban JC, Jung B, Futier E, et al. Practices of end-of-life decisions in 66 southern French ICUs 4 years after an official legal framework: a 1-day audit. Anaesth Crit Care Pain Med. 2015:34(2):73-7.

76. Azoulay E, Metnitz B, Sprung CL, Timsit J-F, Lemaire F, Bauer P, et al. End-of-life practices in 282 intensive care units: data from the SAPS 3 database. Intensive Care Med. 2009;35(4):623-30.

77. Lecuyer L, Chevret S, Thiery G, Darmon M, Schlemmer B, Azoulay E. The ICU trial: a new admission policy for cancer patients requiring mechanical ventilation. Crit Care Med. 2007;35(3):808-14.

78. Lobo SM, De Simoni FHB, Jakob SM, Estella A, Vadi S, Bluethgen A, et al. Decision-making on withholding or withdrawing life support in the ICU: a worldwide perspective. Chest. 2017;152(2):321-9.

79. Heyland DK, Dodek P, Mehta S, Cook D, Garland A, Stelfox HT, et al. Admission of the very elderly to the intensive care unit: family members' perspectives on clinical decision-making from a multicenter cohort study. Palliat Med. 2015;29(4):324-35.

80. Hua M, Halpern SD, Gabler NB, Wunsch H. Effect of ICU strain on timing of limitations in life-sustaining therapy and on death. Intensive Care Med. 2016;42(6):987-94.

81. Milbrandt EB, Eldadah B, Nayfield S, Hadley E, Angus DC. Toward an integrated research agenda for critical illness in aging. Am J Respir Crit Care Med. 2010;182(8):995-1003.

82. Nin N, Lorente JA, De Paula M, Fernández-Segoviano P, Peñuelas O, Sánchez-Ferrer A, et al. Aging increases the susceptibility to injurious mechanical ventilation. Intensive Care Med. 2008;34(5):923-31. 
83. Ray P, Birolleau S, Lefort Y, Becquemin M-H, Beigelman C, Isnard R, et al Acute respiratory failure in the elderly: etiology, emergency diagnosis and prognosis. Crit Care. 2006;10(3):R82.

84. Rubenfeld GD, Caldwell E, Peabody E, Weaver J, Martin DP, Neff M, et al. Incidence and outcomes of acute lung injury. N Engl J Med. 2005;353(16):1685-93.

85. Bellani G, Laffey JG, Pham T, Fan E, Brochard L, Esteban A, et al. Epidemiology, patterns of care, and mortality for patients with acute respiratory distress syndrome in intensive care units in 50 countries. JAMA. 2016;315(8):788-800.

86. Esteban A, Anzueto A, Frutos F, Alía I, Brochard L, Stewart TE, et al. Characteristics and outcomes in adult patients receiving mechanical ventilation: a 28-day international study. JAMA. 2002;287(3):345-55.

87. Ely EW, Wheeler AP, Thompson BT, Ancukiewicz M, Steinberg KP, Bernard GR. Recovery rate and prognosis in older persons who develop acute lung injury and the acute respiratory distress syndrome. Ann Intern Med. 2002;136(1):25-36.

88. Angus DC, Linde-Zwirble WT, Lidicker J, Clermont G, Carcillo J, Pinsky MR. Epidemiology of severe sepsis in the United States: analysis of incidence, outcome, and associated costs of care. Crit Care Med. 2001;29(7):1303-10

89. Karakus A, Haas LEM, Brinkman S, de Lange DW, de Keizer NF. Trends in short-term and 1-year mortality in very elderly intensive care patients in the Netherlands: a retrospective study from 2008 to 2014. Intensive Care Med. 2017:43(10):1476-84.

90. de Rooij SE, Govers A, Korevaar JC, Abu-Hanna A, Levi M, de Jonge E. Short-term and long-term mortality in very elderly patients admitted to an intensive care unit. Intensive Care Med. 2006;32(7):1039-44.

91. Kim S, Han H-S, Jung H, Kim K, Hwang DW, Kang S-B, et al. Multidimensional frailty score for the prediction of postoperative mortality risk. JAMA Surg. 2014;149(7):633-40.

92. Choi J, Tate JA, Donahoe MP, Ren D, Hoffman LA, Chasens ER. Sleep in family caregivers of ICU survivors for two months post-ICU discharge. Intensive Crit Care Nurs. 2016;37:11-8.

93. Lin F, Chaboyer W, Wallis M. A literature review of organisational, individual and teamwork factors contributing to the ICU discharge process. Aust Crit Care. 2009;22(1):29-43.

94. Town JA, Churpek MM, Yuen TC, Huber MT, Kress JP, Edelson DP. Relationship between ICU bed availability, ICU readmission, and cardiac arrest in the general wards. Crit Care Med. 2014;42(9):2037-41.

95. Niven DJ, Bastos JF, Stelfox HT. Critical care transition programs and the risk of readmission or death after discharge from an ICU: a systematic review and meta-analysis. Crit Care Med. 2014;42(1):179-87.

96. van Sluisveld N, Bakhshi-Raiez F, de Keizer N, Holman R, Wester G, Wollersheim $\mathrm{H}$, et al. Variation in rates of ICU readmissions and post-ICU in-hospital mortality and their association with ICU discharge practices. BMC Health Serv Res. 2017:17(1):281.

97. Guidet B, De Lange DW, Christensen S, Moreno R, Fjølner J, Dumas $\mathrm{G}$, Flaatten $\mathrm{H}$. Attitudes of physicians towards the care of critically ill elderly patients - a European survey. Acta Anaesthesiol Scand. 2018;62:207-19.

98. Somme D, Lazarovici C, Dramé M, Blanc P, Lang PO, Gauvain JB, et al. The geriatric patient: use of acute geriatrics units in the emergency care of elderly patients in France. Arch Gerontol Geriatr. 2011;52(1):40-5.

99. Somme D, Andrieux N, Guérot E, Lahjibi-Paulet H, Lazarovici C, Gisselbrecht $\mathrm{M}$, et al. Loss of autonomy among elderly patients after a stay in a medical intensive care unit (ICU): a randomized study of the benefit of transfer to a geriatric ward. Arch Gerontol Geriatr. 2010;50(3):e36-40.

100. Boddaert J, Raux M, Khiami F, Riou B. Perioperative management of elderly patients with hip fracture. Anesthesiology. 2014;121(6):1336-41.

101. Boddaert J, Cohen-Bittan J, Khiami F, Le Manach Y, Raux M, Beinis $J-Y$, et al. Postoperative admission to a dedicated geriatric unit decreases mortality in elderly patients with hip fracture. PLOS ONE. 2014;9(1):e83795

102. Soliman IW, Cremer OL, de Lange DW, Slooter AJC, van Delden JHJM, van Dijk D, et al. The ability of intensive care unit physicians to estimate long-term prognosis in survivors of critical illness. J Crit Care. 2018:43:148-55.

103. Herridge MS, Chu LM, Matte A, Tomlinson G, Chan L, Thomas C, et al The RECOVER program: disability risk groups and 1-year outcome after
7 or more days of mechanical ventilation. Am J Respir Crit Care Med. 2016;194(7):831-44.

104. Heyland DK, Garland A, Bagshaw SM, Cook D, Rockwood K, Stelfox HT, et al. Recovery after critical illness in patients aged 80 years or older: a multi-center prospective observational cohort study. Intensive Care Med. 2015;41(11):1911-20.

105. Khouli H, Astua A, Dombrowski W, Ahmad F, Homel P, Shapiro J, et al. Changes in health-related quality of life and factors predicting longterm outcomes in older adults admitted to intensive care units. Crit Care Med. 2011;39(4):731-7.

106. Iwashyna TJ, Ely EW, Smith DM, Langa KM. Long-term cognitive impairment and functional disability among survivors of severe sepsis. JAMA. 2010;304(16):1787-94.

107. Wassenaar A, de Reus J, Donders ART, Schoonhoven L, Cremer OL, de Lange DW, et al. Development and validation of an abbreviated questionnaire to easily measure cognitive failure in ICU survivors: a multicenter study. Crit Care Med. 2018;46(1):79-84.

108. Wolters AE, Peelen LM, Veldhuijzen DS, Zaal IJ, de Lange DW, Pasma $W$, et al. Long-term self-reported cognitive problems after delirium in the intensive care unit and the effect of systemic inflammation. J Am Geriatr Soc. 2017;65(4):786-91.

109. Boumendil A, Angus DC, Guitonneau A-L, Menn A-M, Ginsburg C, Takun $K$, et al. Variability of intensive care admission decisions for the very elderly. PLOS ONE. 2012;7(4):e34387.

110. Guidet B, Leblanc G, Simon T, Woimant M, Quenot J-P, Ganansia O, et al. Effect of systematic intensive care unit triage on long-term mortality among critically ill elderly patients in France: a randomized clinical trial. JAMA. 2017;318(15):1450-9.

111. Sacanella E, Pérez-Castejón JM, Nicolás JM, Masanés F, Navarro M, Castro $P$, et al. Functional status and quality of life 12 months after discharge from a medical ICU in healthy elderly patients: a prospective observational study. Crit Care. 2011;15(2):R105.

112. Villa P, Pintado M-C, Luján J, González-García N, Trascasa M, Molina R, et al. Functional status and quality of life in elderly intensive care unit survivors. J Am Geriatr Soc. 2016:64(3):536-42.

113. Ferrante LE, Pisani MA, Murphy TE, Gahbauer EA, Leo-Summers LS, Gill TM. Functional trajectories among older persons before and after critical illness. JAMA Intern Med. 2015;175(4):523-9.

114. de Rooij SEJA, Govers AC, Korevaar JC, Giesbers AW, Levi M, de Jonge E. Cognitive, functional, and quality-of-life outcomes of patients aged 80 and older who survived at least 1 year after planned or unplanned surgery or medical intensive care treatment. J Am Geriatr Soc. 2008;56(5):816-22.

115. van der Schaaf $M$, Beelen A, Dongelmans DA, Vroom MB, Nollet F. Functional status after intensive care: a challenge for rehabilitation professionals to improve outcome. J Rehabil Med. 2009;41(5):360-6.

116. Griffiths J, Hatch RA, Bishop J, Morgan K, Jenkinson C, Cuthbertson BH, et al. An exploration of social and economic outcome and associated health-related quality of life after critical illness in general intensive care unit survivors: a 12-month follow-up study. Crit Care. 2013;17(3):R100.

117. Kaarlola A, Tallgren M, Pettilä V. Long-term survival, quality of life, and quality-adjusted life-years among critically ill elderly patients. Crit Care Med. 2006;34(8):2120-6.

118. Hoffman KR, Loong B, Haren FV. Very old patients urgently referred to the intensive care unit: long-term outcomes for admitted and declined patients. Crit Care Resusc. 2016;18(3):157-64.

119. Cameron Jl, Chu LM, Matte A, Tomlinson G, Chan L, Thomas C, et al. One-year outcomes in caregivers of critically ill patients. N Engl J Med. 2016;374(19):1831-41.

120. van den Born-van Zanten SA, Dongelmans DA, Dettling-lhnenfeldt $D$, Vink R, van der Schaaf M. Caregiver strain and posttraumatic stress symptoms of informal caregivers of intensive care unit survivors. Rehabil Psychol. 2016;61(2):173-8.

121. Comini L, Rocchi S, Bruletti G, Paneroni M, Bertolotti G, Vitacca M. Impact of clinical and quality of life outcomes of long-stay ICU survivors recovering from rehabilitation on caregivers'burden. Respir Care. 2016;61(4):405-15.

122. Vitacca M, Barbano L, Vanoglio F, Luisa A, Bernocchi P, Giordano A, et al. Does 6-month home caregiver-supervised physiotherapy improve post-critical care outcomes?: a randomized controlled trial. Am J Phys Med Rehabil. 2016:95(8):571-9. 
123. Kass JE, Castriotta RJ, Malakoff F. Intensive care unit outcome in the very elderly. Crit Care Med. 1992;20:1666-71.

124. Chelluri L, Pinsky MR, Donahoe MP, Grenvik A. Long-term outcome of critically ill elderly patients requiring intensive care. JAMA. 1993;269:3119-23.

125. Broslawski GE, Elkins M, Algus M. Functional abilities of elderly survivors of intensive care. J Am Osteopath Assoc. 1995;95:712-7.

126. Montuclard L, Garrouste-Orgeas M, Timsit JF, Misset B, De Jonghe B, Carlet J. Outcome, functional autonomy, and quality of life of elderly patients with a long-term intensive care unit stay. Crit Care Med. 2000;28:3389-95.

127. Udekwu P, Gurkin B, Oller D, Lapio L, Bourbina J. Quality of life and functional level in elderly patients surviving surgical intensive care. J Am Coll Surg. 2001;193:245-9.
128. Tabah A, Philippart F, Timsit JF, Willems V, Français A, Leplège A, Carlet J, Bruel C, Misset B, Garrouste-Orgeas M. Quality of life in patients aged 80 or over after ICU discharge. Crit Care. 2010;14(1):R2.

129. Andersen FH, Flaatten H, Klepstad P, Romild U, Kvåle R. Long-term survival and quality of life after intensive care for patients 80 years of age or older. Ann Intensive Care. 2015;5:53.

130. Level C, Tellier E, Dezou P, Chaoui K, Kherchache A, Sejourné P, et al. Outcome of older persons admitted to intensive care unit, mortality, prognosis factors, dependency scores and ability trajectory within 1 year: a prospective cohort study. Aging Clin Exp Res. 2018;30(9):1041-51.

\section{Submit your manuscript to a SpringerOpen ${ }^{\circ}$ journal and benefit from:}

- Convenient online submission

- Rigorous peer review

- Open access: articles freely available online

- High visibility within the field

- Retaining the copyright to your article

Submit your next manuscript at $\boldsymbol{\nabla}$ springeropen.com 